Article

\title{
Academic Performance and Physical Activities as Positive Factors for Life Satisfaction among University Students
}

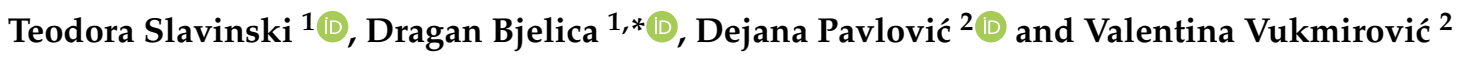 \\ 1 Faculty of Organizational Sciences, University of Belgrade, 11000 Belgrade, Serbia; \\ teodora.slavinski@fon.bg.ac.rs \\ 2 Institute of Economic Sciences, 11000 Belgrade, Serbia; dejana.pavlovic@ien.bg.ac.rs (D.P.); \\ valentina.vukmirovic@ien.bg.ac.rs (V.V.) \\ * Correspondence: dragan.bjelica@fon.bg.ac.rs; Tel.: +381-64-1284-885
}

Citation: Slavinski, T.; Bjelica, D.;

Pavlović, D.; Vukmirović, V.

Academic Performance and Physical Activities as Positive Factors for Life Satisfaction among University

Students. Sustainability 2021, 13, 497. https://doi.org/10.3390/su13020497

Received: 30 October 2020

Accepted: 4 January 2021

Published: 7 January 2021

Publisher's Note: MDPI stays neutral with regard to jurisdictional clai$\mathrm{ms}$ in published maps and institutional affiliations.

Copyright: $(\odot 2021$ by the authors. Licensee MDPI, Basel, Switzerland. This article is an open access article distributed under the terms and conditions of the Creative Commons Attribution (CC BY) license (https:// creativecommons.org/licenses/by/ $4.0 /)$.

\begin{abstract}
Life satisfaction influences sustainable personal growth among students by ensuring that they more firmly apply themselves in their education. Universities represent an environment where students may improve their life satisfaction through better academic performance and being engaged in extracurricular sport. This study evaluates life satisfaction (LS) among university students, 18 to 28 years of age to confirm whether academic performance, involvement in sports and physical activity are factors relating to higher levels of LS among university students. The study uses the Brief Multidimensional Life Satisfaction Scale. Over a three-year timeframe, a questionnaire was administered to a sample of 875 students across areas of study in institutions of higher education in Serbia. The data were analyzed using Mann-Whitney and Kruskal-Wallis tests. LS among students is found to be significantly improved under the following conditions: removing the burden to pay for one's tuition, having a better Grade Point Average (GPA) as well as being involved in sport. Moreover, the optimum level of physical activity to positively affect LS is found to be four to five hours a week.
\end{abstract}

Keywords: university students; life satisfaction; sport participation; academic achievement; demobehavioral characteristics; sustainable community; social sustainability

\section{Introduction}

Life satisfaction (LS) is the overall personal assessment of one's environment and circumstances. One's positive perception of satisfaction with one's overall life or its specific components plays a crucial role in achieving one's goals. Sustainable LS is an indispensable factor in seeking to develop oneself. Several reports have shown that subjective well-being, reflected through achieved high levels of LS components, plays a key role in building sustainable communities and maintaining a healthy life [1,2]. However, this phenomenon can be quite challenging to manage in transitional stages of life, which are commonly accompanied by numerous stressors. Owing to the necessity of adapting to a new environment, taking on new academic responsibilities and dealing with stress originating from them, attending university represents a stressful time in a young person's life $[3,4]$. Facing serious consequences for their actions, while making the first steps into adulthood by starting a new chapter of their life that is more independent than childhood yet not full adulthood, university students are especially vulnerable when it comes to life satisfaction management and their performance as students may suffer as a result.

It has been indicated that multiple factors may influence life satisfaction (LS) among university students. The existing body of literature highlights that LS is largely influenced by one's contentment with social and family life [5], health [6], academic pursuits [7], educational growth [8] and the ability to desensitize from extreme emotions and to resist negative emotional states caused by stress. Academic stress, which is mainly driven by the efforts of students to successfully respond to university demands, is recognized as a major 
factor which negatively influences perceived LS among university attendants [9]. Stressful situations, which directly threaten one's personal perception of life satisfaction, are especially pronounced in university students when taking their final exams [10]. Moreover, achieving high academic performance (commonly expressed by high value of grade point average (GPA) [11]) is usually followed by higher anxiety and tension among those who strive to earn "straight A's". Nevertheless, stressful situations are not related exclusively to those with high GPA-according to Garber et al. [12] poor academic performance also increases stress levels. Although the authors do agree that the stress that accompanies achieving a high GPA score is a direct threat to life satisfaction of university students [13], it is not the only academic trigger that influences LS decline- this phenomenon may correlate with the learning environment [14], education quality [15] or limitations placed on acquiring financial support for funding one's education [16].

Financial stability is repeatedly shown to have a significant impact on a university student's perceived level of LS, as financial burdens disallow students to obtain their education, reach their potential and earn their university diploma [17]. Financial constraints and limited financial aid may have an unfavorable impact on students' interest in actively participating in curricular and extracurricular activities, which might result in raised levels of anxiety and decreased motivation [18]. Furthermore, university students are faced with financial uncertainty which decreases LS [19]; thereby, they experience tension while performing day-to-day and academic tasks and they feel less happy than their peers. Therefore, it has been established that an unfavorable financial situation negatively influences one's perceived satisfaction with university life and life in general [20] and that due to debt incurred in one's education, this form of dissatisfaction can be prolonged, even long after graduation [21], so it can have lifelong consequences to the individual.

As opposed to aggravating factors, there is evidence that university stress may be reduced when engaging in sport activities [22]. Von Rosen et al. [23] promoted sport activities as an effective tool in young adults for developing their potential to cope with stress and negative emotions, so it has been considered to be a useful solution to combat stress [24]. It can be especially beneficial in adapting to new environments (such as youth transitioning from secondary to higher education), when young people experience higher levels of stress and anxiety than usual [25]. However, although it has been noted that involvement in physical activity may have an overall positive influence on improving one's quality of life [26], when transitioning to a university setting, youth tend to refocus their activities to focus on studies and university life, rather than persisting with any prior sports engagement under the assumption it will interfere with their academic performance [27].

However, Gomez-Pinilla and Hillman [28] suggest a positive link between engagement in physical activity and critical brain functions, resulting in improved learning, memory abilities and academic performance. Moreover, university students who participate in physical activities are reported to possess better mental health and personal contentment [29] and they maintain a healthy body weight [30] more successfully than their peers who are physically inactive. Since gaining and losing weight (measured by changes in body mass index (BMI)) are found to be common physical responses of young adults when facing academic and social concerns related to their university experience, sport involvement may notably serve to reduce dramatic body image changes, as high BMI has been shown to be in direct correlation to depression by causing lower overall life quality [31,32]. More precisely, José Alberto Laredo-Aguilera et al. [33] have pointed out that the risk of falling into depressive states is usually twice as high for "overweight" individuals in comparison with those fitting the "normal" or "underweight" range. As increased BMI has also been reported to correspond to academic underachievement [34], university students who incorporate practicing sports into their everyday life routine achieve not only mental and physical well-being, but also potentially improve their academic performance [35] and social relations overall [36].

Although there are numerous studies examining the triggers for declining life satisfaction in university students, they are mostly one-way; Kyeong Joo Lee and Sang Min Lee [37] 
argued that students are exposed to multiple stressors on a daily basis, due to academic pressure, social issues and financial problems, which significantly influence their personal happiness and overall well-being [38]. Antaramian [39] and Reisbig et al. [40] pinpointed that the burden of maintaining a high GPA and not acquiring one are both extremely stressful, so that this favorably impacts not only achieved levels of satisfaction with university experience but with life in general. Abell [41] stated that the burden to pay for one's tuition can lead to such a harmful dissatisfaction in young adults that it often has its reflection in university students' motivation loss or poorer academic performance. Although these papers shed light on controversial areas that threaten one's personal perception of life satisfaction, they do not examine potential revitalizing actions suitable for sustainable LS management among university students. In contrast, this study sets out to assess how university students view separate components that comprise their individual LS in order to gauge if the addition of improved GPA or sport activities can positively influence LS. Starting from the assumption that university students' performance is determined by LS, the authors examine whether an external factor, such as involvement in sports, is able to improve personal perception of satisfaction and reduce the negative effects of other triggers that lead to lower LS. Research of LS in Balkan countries, such as the Republic of Serbia, has not been substantially carried out for those 18 to 28 years of age. According to Stanojević et al. Serbian youth belong to a "third of European countries where respondents express lower levels of general LS" [42] noting that, while young people in Serbia live in a European country that has one of the lowest average scores of life satisfaction, they are paradoxically most satisfied with their social life out of the countries surveyed.

Therefore, the aim of the paper is to determine differences in LS among university students in Serbia in relation to academic performance (GPA, last year GPA), demographic (gender), educational characteristics (faculty orientation, financing status) and involvement in sport activities. Therein, the paper seeks to answer the following questions:

1. Is academic performance a factor in determining LS among university students?

2. Is engagement in sport a determining factor for improving LS among university students?

Based on this background, there are two main hypotheses which address the concerns in the literature review while taking into account the broad scope of international projects. The hypotheses are a synthesis of several research questions the authors of this work have carried out in other international projects, examining student engagement beyond formal curriculum, life satisfaction and academic performance.

Hypothesis 1. Students who achieve better academic performance are also more likely to have higher levels of life satisfaction.

Hypothesis 2. Students engaged in physical activities are more likely to have higher levels of life satisfaction.

\section{Methodology}

\subsection{Research Design and Hypothesis}

Although the (university) student experience represents a stressful time of life for a young person whatever the discipline he or she has chosen to study, the consequences of such stress have astonishing consequences on their overall life satisfaction. Despite the fact that education is an important factor in creating sustainable communities, education in the function of sustainability loses its significance if community members are "educated and unhappy". Although one of the important drivers of such dissatisfaction is equated with the psychological burden that students struggle with in order to achieve high academic success (as a higher GPA score is usually associated with future life benefits, such as gainful employment [43] or higher salary [44] and represents key selection criteria for postgraduate studies [45]), this does not mean that dissatisfaction will be expressed only according to faculty experience. 
To better illustrate this point, students being forced to finance their own studies furthers their burden on limited shared family resources which can negatively contribute to their satisfaction and diminish their performance at university. This is often the case in Serbia where the vast majority of young people remain unemployed during their studies, and only the best performing are able to earn state-sponsored, merit-based scholarships [46]. It is therefore generally difficult to avoid financial burdens while carrying out studies to earn a tertiary degree. Furthermore, multiple sources suggest that sport has a revitalizing effect on life satisfaction (a concept known since antiquity as Mens sana in corpore sano). We therefore aimed to examine how sport, when included in one's life routine can contribute to overall life satisfaction as its own positive factor. Since it has been shown that the positive effects of sports are far-reaching and go beyond only physical and mental benefits [47], the research also aimed to explore whether it could impact satisfaction with family, social, university and overall life.

\subsection{Sample and Setting}

The current study was carried out from 2015 to 2018, in 15 institutions of higher learning from Serbia which included both publicly and privately-run universities. The research sample was therefore more heterogeneous than that of the 2016 study [48] since it included a broader pool of students from which to draw. Consisting of 905 undergraduate and post-graduate students from disparate educational backgrounds, 875 research participants filled out the questionnaire. By percentage, the research sample was composed of students who were divided by study group into three areas of study: social sciences and humanities (47\%); natural sciences, mathematics and medicine (6.6\%); technology and engineering sciences $(46.3 \%)$. The research participants were 18-28 years of age and were more representative of female $(523,59.8 \%)$ than male students $(352,40.2 \%)$. A fuller list of all demographics is presented in Table 1 . By percentage, $93 \%$ of respondents were bachelor's level students aged 18-22. Only 7\% were master's and doctoral students aged 22-28.

Table 1. Sample characteristics.

\begin{tabular}{cc}
\hline Characteristics & $\mathbf{n}(\mathbf{\%})$ \\
Sex & \\
Male & $352(40.2)$ \\
Female & $523(59.8)$ \\
Area of study & \\
Social sciences and humanities & $411(47.0)$ \\
Natural sciences, mathematics and medicine & $58(6.6)$ \\
Technology and engineering sciences & $405(46.4)$ \\
Financing status of their education & \\
State scholarship & $598(68.3)$ \\
Self-financing & $277(31.7)$ \\
Involvement in sport & \\
Yes & $537(61.4)$ \\
No & $338(38.6)$ \\
Year of study & $319(36.5)$ \\
First and second & $495(56.5)$ \\
Third and fourth & $61(7.0)$ \\
\hline
\end{tabular}

\subsection{Procedure}

Prior to conducting the research, the study proposal was submitted to the Institutional Review Board of the University of Belgrade in order to be granted permission to do so. Upon approval, the questionnaire was created in both paper and electronic formats to be distributed to students attending their tertiary education across private and public institutions of higher learning in Serbia. The participating students were administered these questionnaires from 2015 to 2018. Participants were selected through volunteering freely 
from student organizations and being asked by the professor and researchers (who are authors of this paper) at the individual participating departments. Participant responses were gathered through email and paper-based forms which were delivered from the Public Relationship (PR) services operating within the university administration. Surveys were conducted anonymously and only collected non-confidential data. The survey was only administered once to each participant and doubling of the participants is not present due to the fact that these students were only administered the survey directly once.

The response rate was approximately 18\% (about 4700 questionnaires were sent to student addresses and 300 students were directly contacted to fill out paper-based forms). Given that all respondents were contacted directly through student-related contacts, the only criterion was that any currently active student could take part in the research.

\subsection{Independent Variables}

When compiling the questionnaires, we took into consideration the following criteria:

1. Academic performance and area of study (GPA, area of study, scholarship/funding status);

2. Demographic and behavioral characteristics (BMI, gender);

3. Activity in sport (type of sport, sport involvement, weekly time spent doing physical activity).

\subsubsection{Grade Point Average}

Based on self-reports, overall GPA was calculated by adding the score of all grades (A) of passed exams then dividing this number by the total number of exams passed (P).

$$
\mathrm{A} / \mathrm{P}=\mathrm{GPA}
$$

GPA was also calculated for the last academic year attended in like manner, by which the total number of exams passed in the last academic year (PY) was divided into the total score of the grade achieved (AY).

$$
\mathrm{AY} / \mathrm{PY}=\mathrm{GPA} \text { (in the last academic year) }
$$

The grading system used within the university system of Serbia ranges from 5 to 10 . The minimum GPA to pass an exam is 6. The maximum is 10 .

\subsubsection{Weekly Time Spent in Physical Activity}

Following the example of research from 2016 [48], students were categorized into three groups according to the number of hours spent doing physical activity on a weekly basis-insufficiently active (less than $3 \mathrm{~h}$ per week), active (between 3 and $10 \mathrm{~h}$ per week) and very active (more than $10 \mathrm{~h}$ per week).

The data plotted out in Figure 1 indicates that there is an exceptional correlation between overall GPA and GPA in the final year of studies, but in relation to physical activity, no correlation was observed. Therefore, these variables will be considered separately in the research. 


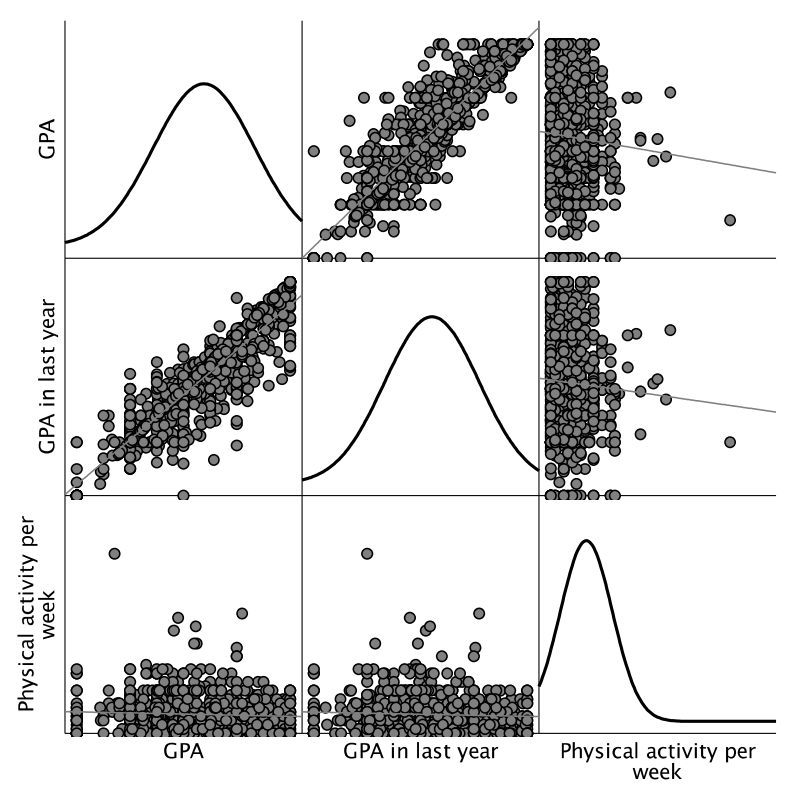

Figure 1. Scatterplot between overall GPA, GPA in the final year of studies and physical activity per week.

\subsubsection{BMI}

Respondents were asked to include only their height $(\mathrm{H})$ and weight $(\mathrm{W})$, for which the authors calculated their BMI based on $\mathrm{W} / \mathrm{H}=\mathrm{BMI}$. Following guidelines laid out by the World Health Organization (WHO), respondents scoring $<18.5$ were considered underweight, from 18.5 to 24.9 were considered normal and those $>25$ were overweight [49].

\subsection{Dependent Variables}

The following components of life satisfaction based on Brief Multidimensional Students' Life Satisfaction Scale (BMSLSS) have been analyzed as a dependent variable: 1. university experience satisfaction, 2 . oneself satisfaction, 3 . current place of residence satisfaction, 4 . family life satisfaction, 5 . social life satisfaction, 6 . overall life satisfaction.

Students filled in the questionnaire themselves. Response choices for the BMSLSS are on a five-point Likert-type scale (" 1 - very dissatisfied", "2—-dissatisfied", "3-moderately satisfied", "4-satisfied", "5-very satisfied") for a questionnaire of six questions. Higher scores show more existential LS.

\subsection{Data Analysis}

Data analysis was prepared in SPSS 26.0. The Mann-Whitney and Kruskal-Wallis tests were used to examine the differences between the variables, incorporating the Bonferroni correction test as a post-test for comparison of three or more groups. The research results are described by two parameters - mean and standard deviation, obtaining the observed effect according to $p$-value $(p \leq 0.05)$. Furthermore, the comparative analysis between a similar study published in 2016 and this research will be presented.

\subsection{Reliability and Validity Analysis}

In order to assess reliability of the scale we did an internal consistency test with Cronbach alpha. Cronbach's alpha coefficient for BMSLSS scale is 0.8. The BMSLSS has been used in numerous studies, including measuring life satisfaction among public high school adolescents [50], where validation of the scale was confirmed for students [51], as well as being deemed applicable/adaptable for respondents 8-18 years of age [52]. In order to compare the results with a similar study published in 2016 [48] at the University of Belgrade, Faculty of Organizational Sciences, the same scope for the 5-point BMSLSS scale was used. 


\section{Results}

This study provides findings on the LS of university students in comparison to their academic performance and demo-behavioral characteristics, focusing on their involvement in sport as a factor determining LS. The LS parameters which are observed in this study were considered to be factors which directly influence physical and psychological health as well as overall well-being of university students.

\subsection{Academic Performance and Life Satisfaction}

According to Table 2, a statistically significant difference is found to exist between students who have only earned "satisfactory" grades (i.e., those students whose GPA was 7.5 to 8.5 ) and "excellent" students (i.e., those students whose GPA was 8.5 to 10) in terms of LS and three components making up LS. Students whose grades were "satisfactory" have expressed lower levels of satisfaction with their university experience and lower satisfaction with family life than students whose grades were "excellent".

Table 2. Life Satisfaction (LS) evaluation components (Mean \pm SD) by grade point average (GPA) group, GPA for the last year attended, financing status of education, business and non-business curriculum and area of study.

\begin{tabular}{|c|c|c|c|c|c|c|c|}
\hline & & $\begin{array}{l}\text { University } \\
\text { Experience }\end{array}$ & Oneself & $\begin{array}{l}\text { Current Place of } \\
\text { Residence }\end{array}$ & Family Life & Social Life & Overall Life \\
\hline Item & $\mathbf{N}$ & $\mathbf{M} \pm \mathbf{S D}$ & $\mathbf{M} \pm \mathbf{S D}$ & $\mathbf{M} \pm \mathbf{S D}$ & $\mathbf{M} \pm \mathbf{S D}$ & $\mathbf{M} \pm \mathbf{S D}$ & $\mathbf{M} \pm \mathbf{S D}$ \\
\hline \multicolumn{8}{|c|}{ GPA group } \\
\hline Under 7.5 & 201 & $3.17 \pm 1.011$ & $3.91 \pm 0.822$ & $3.95 \pm 0.994$ & $3.97 \pm 1.012$ & $3.89 \pm 0.95$ & $3.81 \pm 0.864$ \\
\hline $7.51-8.5$ & 407 & $3.4 \pm 1.002$ & $3.89 \pm 0.82$ & $4.01 \pm 0.999$ & $4.10 \pm 0.909$ & $3.93 \pm 0.874$ & $3.78 \pm 0.766$ \\
\hline $8.51-10$ & 267 & $3.7 \pm 1.011$ & $4.0 \pm 0.845$ & $3.97 \pm 0.986$ & $4.19 \pm 0.904$ & $3.92 \pm 0.926$ & $3.95 \pm 0.891$ \\
\hline$p$ value & & $<0.01 * *$ & 0.095 & 0.667 & $<0.05^{*}$ & 0.933 & $<0.01 * *$ \\
\hline \multicolumn{8}{|c|}{ Last year's GPA } \\
\hline Under 7.5 & 164 & $3.23 \pm 0.987$ & $3.91 \pm 0.842$ & $3.97 \pm 0.975$ & $3.97 \pm 1.030$ & $3.91 \pm 0.923$ & $3.85 \pm 0.89$ \\
\hline $7.51-8.5$ & 373 & $3.36 \pm 1.011$ & $3.87 \pm 0.811$ & $3.96 \pm 1.017$ & $4.08 \pm 0.899$ & $3.92 \pm 0.896$ & $3.76 \pm 0.777$ \\
\hline $8.51-10$ & 338 & $3.63 \pm 1.003$ & $4.0 \pm 0.839$ & $4.01 \pm 0.977$ & $4.18 \pm 0.919$ & $3.91 \pm 0.913$ & $3.92 \pm 0.852$ \\
\hline$p$ value & & $<0.01 * *$ & $<0.01 * *$ & 0.786 & 0.054 & 0.982 & $<0.01 * *$ \\
\hline \multicolumn{8}{|c|}{ Gender } \\
\hline Male & 352 & $3.43 \pm 1.013$ & $3.95 \pm 0.808$ & $3.93 \pm 1.018$ & $4.0 \pm 0.907$ & $3.81 \pm 0.887$ & $3.82 \pm 0.784$ \\
\hline Female & 523 & $3.44 \pm 1.016$ & $3.91 \pm 0.843$ & $4.02 \pm 0.975$ & $4.16 \pm 0.948$ & $3.98 \pm 0.914$ & $3.85 \pm 0.862$ \\
\hline$p$ value & & 0.802 & 0.484 & 0.199 & $<0.01 * *$ & $<0.01 * *$ & 0.460 \\
\hline \multicolumn{8}{|c|}{ Financing status } \\
\hline Scholarship & 598 & $3.56 \pm 1.009$ & $3.95 \pm 0.813$ & $3.99 \pm 0.971$ & $4.17 \pm 0.89$ & $3.93 \pm 0.917$ & $3.89 \pm 0.815$ \\
\hline $\begin{array}{c}\text { Self- } \\
\text { financing }\end{array}$ & 277 & $3.18 \pm 0.981$ & $3.87 \pm 0.86$ & $3.97 \pm 1.04$ & $3.95 \pm 1.01$ & $3.88 \pm 0.885$ & $3.71 \pm 0.853$ \\
\hline$p$ value & & $<0.01 * *$ & 0.244 & 0.951 & $<0.01 * *$ & 0.377 & $<0.01 * *$ \\
\hline \multicolumn{8}{|c|}{ Business/non-business orientation } \\
\hline $\begin{array}{c}\text { Non- } \\
\text { business }\end{array}$ & 599 & $3.27 \pm 1.046$ & $3.88 \pm 0.860$ & $3.95 \pm 1.007$ & $4.04 \pm 0.96$ & $3.86 \pm 0.922$ & $3.77 \pm 0.863$ \\
\hline $\begin{array}{l}\text { Business } \\
p \text { value }\end{array}$ & 276 & $\begin{array}{c}3.8 \pm 0.836 \\
<\mathbf{0 . 0 1} * *\end{array}$ & $\begin{array}{c}4.02 \pm 0.748 \\
<0.05 *\end{array}$ & $\begin{array}{c}4.05 \pm 0.96 \\
\mathbf{0 . 1 6 9}\end{array}$ & $\begin{array}{c}4.22 \pm 0.866 \\
<0.01 * *\end{array}$ & $\begin{array}{c}4.02 \pm 0.865 \\
<0.05 *\end{array}$ & $\begin{array}{c}3.99 \pm 0.736 \\
<0.01 * *\end{array}$ \\
\hline \multicolumn{8}{|c|}{ Area of study } \\
\hline SSH & 411 & $3.18 \pm 1.063$ & $3.86 \pm 0.875$ & $3.93 \pm 1.026$ & $4.01 \pm 0.974$ & $3.88 \pm 0.912$ & $3.74 \pm 0.889$ \\
\hline NSMM & 58 & $3.29 \pm 1.155$ & $3.74 \pm 0.965$ & $3.84 \pm 1.04$ & $4.07 \pm 0.915$ & $3.69 \pm 1.03$ & $3.59 \pm 0.879$ \\
\hline TES & 405 & $3.72 \pm 0.855$ & $4.02 \pm 0.746$ & $4.05 \pm 0.945$ & $4.19 \pm 0.89$ & $3.98 \pm 0.879$ & $3.97 \pm 0.74$ \\
\hline$p$ value & & $<0.01 * *$ & $<0.01 * *$ & 0.126 & $<0.01 * *$ & 0.933 & $<0.01 * *$ \\
\hline
\end{tabular}

* Significant at $p \leq 0.05$ level; ** Significant at $p \leq 0.01$ level; SSH—Social sciences and humanities; NSMM-Natural sciences, mathematics and medicine; TES-Technology and engineering sciences.

According to the GPAs reported, similar results were obtained for both overall GPA of all years attended and the GPAs of the last completed year of studies. 
There was a significant statistical difference found in terms of gender and LS, as female students expressed higher levels of satisfaction regarding their social life and family life than their male peers.

University students who have received scholarships also reported higher levels of satisfaction with their university experience and family life than self-financing students. Self-financing students were therefore also less satisfied with their overall LS.

Non-business students expressed lower satisfaction with their university experience, themselves, as well as their social and family life than business students. A statistically significant difference is found between area of study and LS. Interestingly, there is a significant difference between satisfaction with one's social life and student's area of study.

\subsection{Participation in Sport and Life Satisfaction}

In accordance with the assumption that physical activity presents an important factor for achieving well-being and improving overall quality of life, the following results presented comparison between LS components and university student attitudes towards sport engagement (Table 3).

Table 3. LS evaluation components (Mean \pm SD) by involvement in sport (individual/team), membership in sport club and physical activity per week.

\begin{tabular}{|c|c|c|c|c|c|c|c|}
\hline & & $\begin{array}{l}\text { University } \\
\text { Experience }\end{array}$ & Oneself & $\begin{array}{l}\text { Current Place of } \\
\text { Residence }\end{array}$ & Family Life & Social Life & Overall Life \\
\hline Item & $\mathbf{N}$ & $\mathbf{M} \pm \mathbf{S D}$ & $\mathbf{M} \pm \mathbf{S D}$ & $\mathbf{M} \pm \mathrm{SD}$ & $\mathbf{M} \pm \mathbf{S D}$ & $\mathbf{M} \pm \mathbf{S D}$ & $\mathbf{M} \pm \mathrm{SD}$ \\
\hline \multicolumn{8}{|c|}{ BMI } \\
\hline Underweight & 90 & $3.53 \pm 1.104$ & $4.11 \pm 0.854$ & $4.27 \pm 0.845$ & $4.26 \pm 0.931$ & $4.08 \pm 0.89$ & $4.07 \pm 0.832$ \\
\hline $\begin{array}{l}\text { Normal } \\
\text { range }\end{array}$ & 649 & $3.44 \pm 1.021$ & $3.92 \pm 0.811$ & $3.93 \pm 1.001$ & $4.08 \pm 0.93$ & $3.91 \pm 0.894$ & $3.83 \pm 0.827$ \\
\hline $\begin{array}{l}\text { Overweight } \\
p \text { value }\end{array}$ & 136 & $\begin{array}{c}3.38 \pm 0.919 \\
\mathbf{0 . 3 3 4}\end{array}$ & $\begin{array}{l}3.82 \pm 0.879 \\
\quad<0.01 * *\end{array}$ & $\begin{array}{l}4.05 \pm 1.013 \\
\quad<\mathbf{0 . 0 1} * *\end{array}$ & $\begin{array}{c}4.1 \pm 0.957 \\
\quad \mathbf{0 . 1 3 0}\end{array}$ & $\begin{array}{c}3.83 \pm 0.97 \\
\mathbf{0 . 1 2 8}\end{array}$ & $\begin{array}{c}3.71 \pm 0.827 \\
\quad<0.01\end{array}$ \\
\hline \multicolumn{8}{|c|}{ Type of sport involvement } \\
\hline Individual & 529 & $3.4 \pm 1.016$ & $3.92 \pm 0.796$ & $3.98 \pm 0.973$ & $4.1 \pm 0.918$ & $3.9 \pm 0.886$ & $3.85 \pm 0.794$ \\
\hline Team & 196 & $3.49 \pm 0.936$ & $3.97 \pm 0.813$ & $4.06 \pm 0.953$ & $4.16 \pm 0.868$ & $3.91 \pm 0.904$ & $3.89 \pm 0.754$ \\
\hline $\begin{array}{l}\text { No sport } \\
p \text { value }\end{array}$ & 150 & $\begin{array}{c}3.51 \pm 1.104 \\
\mathbf{0 . 1 9 3}\end{array}$ & $\begin{array}{c}3.89 \pm 0.796 \\
\mathbf{0 . 9 5 6}\end{array}$ & $\begin{array}{c}3.89 \pm 0.956 \\
\mathbf{0 . 4 3 7}\end{array}$ & $\begin{array}{c}3.99 \pm 1.065 \\
0.52\end{array}$ & $\begin{array}{c}3.97 \pm 0.983 \\
\mathbf{0 . 3 8 8}\end{array}$ & $\begin{array}{c}3.71 \pm 1.027 \\
\mathbf{0 . 3 1 6}\end{array}$ \\
\hline \multicolumn{8}{|c|}{ Sport club membership } \\
\hline Yes & 151 & $3.56 \pm 1.004$ & $4.09 \pm 0.778$ & $4.07 \pm 0.964$ & $4.22 \pm 0.807$ & $4.02 \pm 0.875$ & $3.97 \pm 0.787$ \\
\hline No & 724 & $3.41 \pm 1.016$ & $3.89 \pm 0.835$ & $3.96 \pm 0.999$ & $4.07 \pm 0.958$ & $3.89 \pm 0.912$ & $3.81 \pm 0.838$ \\
\hline$p$ value & & 0.115 & $<0.01 * *$ & 0.252 & 0.176 & 0.136 & $<0.01 * *$ \\
\hline \multicolumn{8}{|c|}{ Physical activity per week } \\
\hline $\begin{array}{c}\text { Insufficiently } \\
\text { act. }\end{array}$ & 414 & $3.4 \pm 1.052$ & $3.86 \pm 0.874$ & $3.9 \pm 1.02$ & $4.04 \pm 0.989$ & $3.84 \pm 0.963$ & $3.74 \pm 0.894$ \\
\hline Active & 413 & $3.5 \pm 0.974$ & $3.99 \pm 0.773$ & $4.07 \pm 0.936$ & $4.17 \pm 0.89$ & $4.01 \pm 0.837$ & $3.94 \pm 0.757$ \\
\hline $\begin{array}{c}\text { Very active } \\
p \text { value }\end{array}$ & 46 & $\begin{array}{c}3.26 \pm 0.976 \\
\mathbf{0 . 1 3 0}\end{array}$ & $\begin{array}{c}3.96 \pm 0.868 \\
\mathbf{0 . 0 8 9}\end{array}$ & $\begin{array}{c}3.96 \pm 1.192 \\
<0.05 * *\end{array}$ & $\begin{array}{c}3.96 \pm 0.788 \\
\mathbf{0 . 0 7 1}\end{array}$ & $\begin{array}{c}3.76 \pm 0.923 \\
<0.05^{* *}\end{array}$ & $\begin{array}{c}3.8 \pm 0.778 \\
<0.01 * *\end{array}$ \\
\hline
\end{tabular}

** Significant at $p \leq 0.01$ level.

According to Table 3, the results obtained partly confirm that changes in weight correspond to depression and lower LS. Whereas students whose BMI was described as "underweight" also expressed lower levels of satisfaction in themselves and overall LS (Table 3).

There was found to be no difference in LS if a university student was found to engage in team sports or individual sport. Belonging to a sport club also provided higher levels of satisfaction with oneself and one's overall life.

A significant difference was found between LS and intensity of physical activity, as "active" students reported higher levels of overall LS than their "insufficiently active" peers 
(Table 3). Active students were found to express higher levels of satisfaction with LS for their current place of residence, social life and overall life.

\subsection{A Parallel Comparison of LS and Physical Activity per Week in University Students}

Figure 2 illustrates LS in relation to the level of physical activity in hours on a weekly basis as well as in relation to the year of study. Students who had 4 to $5 \mathrm{~h}$ of physical activity per week were satisfied with all factors throughout all levels of study, while dissatisfaction was observed below and above these limits. Students in the first and second year of study, even though they engaged in physical activities for more than $6 \mathrm{~h}$ a week, were dissatisfied with their current place of residence; in master's and doctoral studies, this dissatisfaction was noticeable if they had no physical activity at all. A lack of physical activity in the first and second year of study (less than $2.5 \mathrm{~h}$ ) led to dissatisfaction with oneself and social life, while this trend changed in the third and fourth year; engaging in physical activity for five or more hours per week led to dissatisfaction with oneself and social life. For bachelor's studies students, insufficient physical activity (less than $2.5 \mathrm{~h}$ ) caused dissatisfaction with one's family life. Engaging in physical activity less than $3 \mathrm{~h}$ a week led to dissatisfaction with one's overall life, while $4-5 \mathrm{~h}$ a week of physical activity was found to have a positive impact.
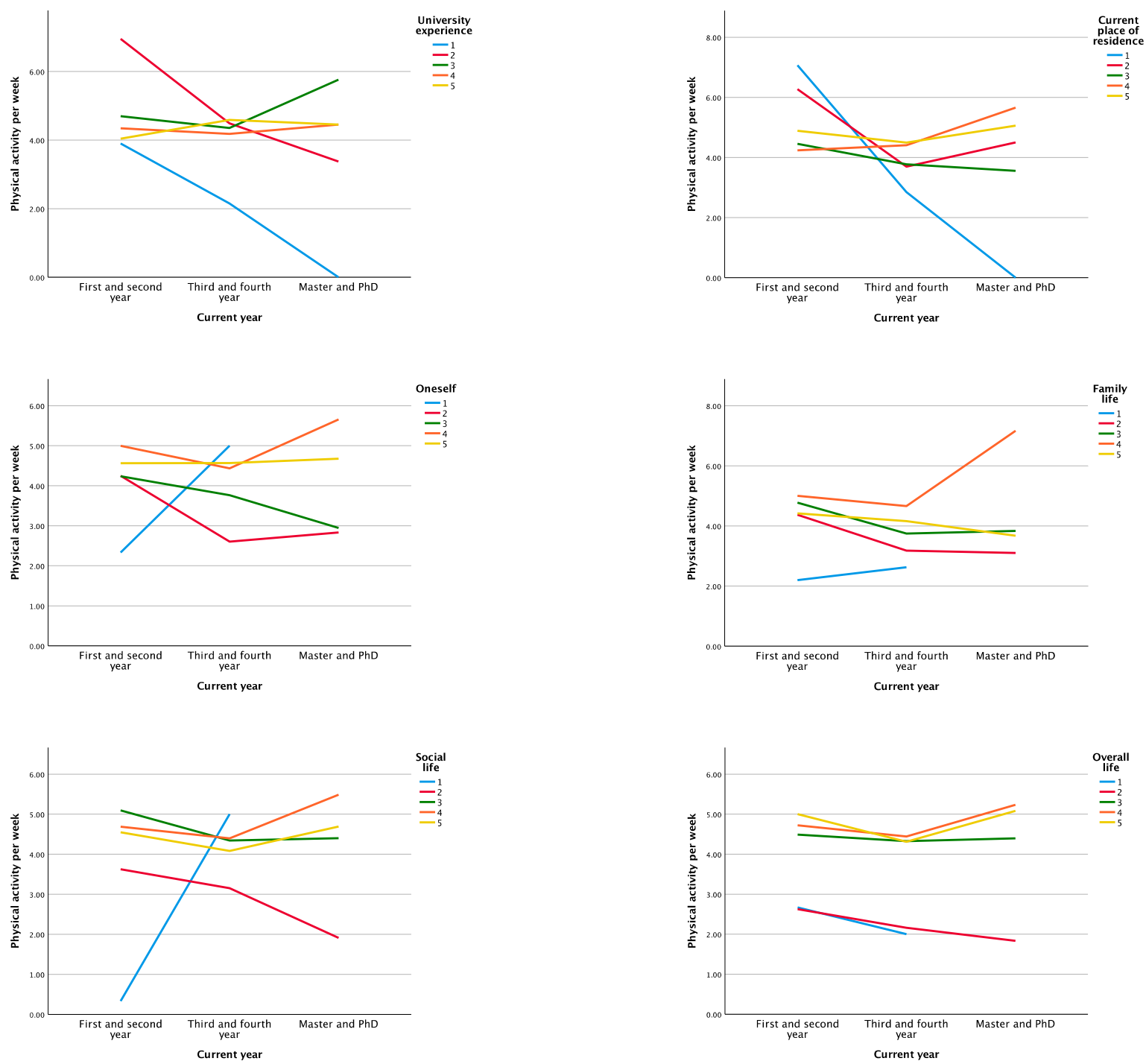

Figure 2. LS evaluation components by students' physical activity per week and year of study (1-very dissatisfied; 2-dissatisfied; 3-moderately satisfied; 4-satisfied; 5-very satisfied). 


\section{Discussion}

\subsection{Academic Performance and Educational Environments Affecting Life Satisfaction}

This study finds that academic achievements of university students (measured by their total GPA and the GPA earned in the most recent year of study) as well as educational and demographic characteristics (self-financing or scholarship, area of education and gender) may be significantly influential on achieving LS in youth. Results related to correlations between GPA and LS among university students reflect the conclusions drawn by Rode [53] and Heffner and Antaramian [54], as respondents who have achieved an overall "excellent" GPA (as well as an "excellent" GPA in their most recent year of study) reported higher levels of satisfaction with their university experience compared to their peers who earned a lower GPA. Even though statistically significant differences between academic achievements measured by GPA and university experience were established by Bjelica and Jovanovic [48], we have found GPA score influential for personal perception of satisfaction with family and overall life as well. This finding concurs with the similar conclusions of both Grass et al. [55] and Steinmeyer et al. [56] who stated that a student's GPA is a deciding factor for their subjective well-being.

In addition to GPA, this research has shown that other factors may be influential regarding one's satisfaction with one's university experience, such as whether one is able to finance one's education or not. This study supports findings that financial independence has an impact on university students' LS [57], concurring with the literature that self-financing students were more affected by stress stemming from financial burdens, resulting in lower levels of well-being [58]. The study presented here also reflects on lower satisfaction with one's family life, as Cloutier and Roy [59] also pointed to several spheres of parental influence on personal finance among undergraduate students affecting one's university experience. University students who have been awarded scholarships show greater satisfaction with their student experience than do their peers who must finance university education out of pocket. It is interesting to note that students who have been awarded scholarships also expressed higher levels of satisfaction with their family life than their peers, which was not established in similar researches conducted in Serbia [48]. As students who are financially dependent on their parents represent the majority of the student population in Serbia, the study's findings related to a significant correlation between a student's satisfaction with their family life and the students' financial status does raise concern about how students perceive satisfaction in Serbia.

Another important finding concerning family LS was that female students expressed higher levels of satisfaction than did their male peers. Although concurring with other studies elsewhere in the literature wherein female respondents generally express higher levels of LS (such as Murphy et al. [60]), what is more striking here is the consistency of this result. A similar conclusion is here drawn regarding satisfaction with social life as well, in which female participants expressed higher levels of satisfaction with their social life. Higher levels of satisfaction among female students could be partially attributable to Serbian social norms which is consistent with Ismael and Fuad [61] who assert that, while women are allowed to seek assistance, asking for assistance in a patriarchal society is a contraindication in masculinity, thereby leading to lower LS. Male students might be under pressure then to not show their emotions and vulnerability or to even ask for support as they are expected to be independent and capable of solving issues on their own. This conclusion concurs with that of Stanojević et al. [42] and Pesic [62] who all emphasize the dominance of patriarchal cultural patterns within Serbia, as a deciding factor in determining LS between males and females. Nonetheless, despite conclusions drawn by Bjelica and Jovanovic [48], this study did not find a significant difference between attitudes of female and male students in the domain of overall life satisfaction.

Finally, it has been established that variation between the academic requirements of studies, influenced by area of study and/or curriculum, may affect the student experience itself. It was therefore reasonable to assume that students studying different fields or at different educational institutions may also possess a dissimilar perception of life satisfaction. 
Although Crosnoe [63] pointed out that regardless whether the field of study focuses on the humanities, the sciences or technology, the same negative factors are reported to influence a university student's overall LS, university students of social sciences and humanities (SSH) have reported decreased levels of satisfaction with almost all LS components compared to university students of technology and engineering sciences (TES). Furthermore, results have confirmed moderate levels of satisfaction achieved by the university attendants with business-oriented majors [64] and it is indicated that they reported higher levels of satisfaction with almost every examined LS segment compared to university students of non-business-oriented courses.

\subsection{Sport Participation as a Factor Influencing Life Satisfaction}

Multiple physical and mental benefits of being physically active in sports have been established in this study as being beneficial for university students. As has been found with Jetzke and Mutz [65], who highlighted the significant role of sport activities in improving the well-being of youth, our study also strongly indicates that university students that participate in sports activities also express higher levels of satisfaction with themselves compared to their peers who did not. More specifically, our study has established that university students who had declared themselves to be physically "active" were more satisfied with their overall life than "insufficiently active" students, supporting the conclusions of Arslan and Akkas [29]. There is a statistical significance found here between a student practicing sports and their satisfaction with their social life.

Our results also point to university students who are involved in sport having higher levels of satisfaction with their social life, which represents a novelty compared to the previously conducted research. While our study did not pursue avenues to further explore the underlying causes, it may be safely presumed, according to other conclusions within the literature, that this is the case because sport activities lead to socialization through the establishing of social ties such as friendships and increasing one's interpersonal network. For instance, Romaguera et al. [66] noted that university students who were physically active did so as a way to spend time with their friends. Moreover, high LS may stem from participation in the activities of a sports community since community-level physical activity can result in a range of mental health benefits [67] and community well-being [68]. However, although Flosdorf et al. [69] found a relationship between membership in a sport community and one's satisfaction with one's social life, our study did not find a distinct relationship between sports membership and one's social life, rather a correlation between one's overall life and oneself.

Schnettler et al. [70] describe university as a turbulent time for youth as they "begin to take responsibility for their own lives, including their food". Their observation suggests that the deterioration of eating habits among students results in "weight gain, obesity, health-related problems, as well as low levels of life satisfaction". Moreover, weight gain and weight loss are reported to be in direct correlation with levels of depression and decreased quality of life caused by depressive states [71]. The study presented here does confirm that BMI is associated with the perception of one's LS. Furthermore, students grouped as "underweight" expressed greater satisfaction with themselves than those who were "overweight". These results are likely related to the students' physical appearance limiting the effect of their self-satisfaction. However, according to Wiklund et al. [72] "the paradox of strong and skinny" stemming from "unhealthy fitness hype" has dramatically affected the body perceptions of millennials, who are the most active users of social media. Furthermore, some results of the study presented here do not confirm the same conclusion, as it was found that "underweight" students expressed lower levels of overall LS than did "overweight" and "normal" participants.

Finally, results presented here indicate the minimal hours that university students should spend practicing sports in order to achieve potential life benefits. However, we have noted that frequency of physical practice radically differs depending on which year university student attends, confirming results both from Bjelica and Jovanovic [48] and Djokovic 
et al. [73]. While transition from high school to university can be dramatically stressful for freshmen [74], it was notable that their needs for sport engagement were the most expressive, as Miller and Hoffman [75] highlighted beneficial effects of physical activity in stress reduction and students' mental health. Contrary to this, Castro-Sanchez et al. [76] noted students' sudden abandonment of physical activities when finishing high school, as they are starting to be predominantly oriented to achievement of high academic performance. The case is not much different with the second year's university attendants, as coping with the workload and psychosocial challenges may be prolonged [77]. As if they assume that they will be more successful if they spend all their time and energy devoted to education [78] or are trying to please parents by "giving academic success priority over ex-

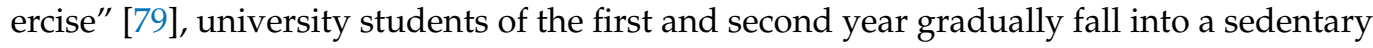
lifestyle by abruptly interrupting their previous physical engagement, which can result in reduction of their personal and academic efficiency. However, the results presented here show that not more than 4-5 weekly hours spent in sports are enough for them to increase levels of all the life satisfaction components, but also that they will feel the first positive effects if they become physically active for just $2.5 \mathrm{~h}$ per week.

Moreover, the same dissatisfaction that was registered in university attendants during the first two years of college was reported by their peers that attended the third and final year of university in cases where they were physically engaged for less than $2 \mathrm{~h}$ per week (or even when there was the absolute lack of physical engagement). The same situation was reported by the university attendants of master's and doctoral levels of study and has been especially related to their dissatisfaction with university experience. Therefore, it is not hard to conclude that university students accept a sedentary lifestyle as the dominant one, which directly jeopardizes their satisfaction with various aspects of their life; Deliens et al. [80] pointed out that sedentary behavior results in "poorer well-being, increased risk of depression, and weaker cognitive functioning".

\section{Limitations and Further Research Directions}

As with the majority of studies, the design of the current study is subject to limitations. Generally, research limitations referring to the participants' subjectivism and the potential of establishing causal relationships are always present in student surveys. Moreover, the number of observed LS components could have been more extensive. However, due to the need to achieve research comprehensibility, not all components were taken into consideration. Another limitation is the research sample, as participants were recruited from universities throughout Serbia; as a result, current findings may not be generalized to students from other countries.

In spite of its limitations, the study certainly adds to a more thorough understanding of LS among youth in Serbia. The sample size is nationally representative, whereas research results provide updated information on the impact of lifestyle choices and academic success on the overall LS of youth in Serbia.

Further research should take into consideration students' extracurricular activities and endeavors related to building social connections, which cannot be quantitatively assessed. Student extracurricular activities are found to have a beneficial impact on their career development and peer relationship improvement, as well as academic institution adaptation [81]. These factors improve the chances of one's employability [82], whereas the feeling of contribution to the academic community [83] and society as a whole, additionally contributes to the perceived level of LS [84]. Likewise, measuring sports results involves quantitative parameters. Nevertheless, measurements in some cases within the student population cannot be performed for the entire population. Most certainly, further research should consider the interconnection of educational administrative systems with student academic and extracurricular activities as well as their LS.

This study has contributed towards enhancing the understanding of life satisfaction phenomenon among the student population in Serbia. The current global crisis caused by the COVID-19 pandemic has motivated the authors to critically review the results once 
again. Increased anxiety and depressive states, cited in the literature as an integral part of the university experience and confirmed by the results of our research, are gaining ground. Strong reaction to the unfolding crisis among students increases anxiety, thus directly impairing their satisfaction with life [85]. This study, due to its time frame of 2016 to 2019, does not take into account shifting trends among the student populace that COVID-19 has caused.

As LS plays a critical role in students' as well as young people's lives, it requires a more extensive approach to analyze separate facets that go into creating overall LS. Through a comparison of research results obtained in 2016 [48] and the results presented in this article, this study has presented indispensable conclusions for better understanding the LS of university students in Serbia. Interpreted in the current COVID-19 context, these results may serve as reference values when examining LS among students during the ongoing pandemic, while expected deviations will quantitatively indicate the extent and presence of negative consequences on the perception of LS.

\section{Conclusions}

In this study, higher GPA was associated with increased satisfaction with university experience and higher satisfaction with family life. Scholarship status emerged as a reliable predictor of perceived satisfaction with university experience and family life, as students who obtained a scholarship reported higher levels of satisfaction on these components of LS. Engagement in sport activities and sport community membership, along with being a student in a field of study related to business, were found to be a predictor of higher satisfaction with oneself. Moreover, business-oriented academic studies were associated with higher levels of satisfaction with university experience as well. According to the results of the research conducted in this paper, higher satisfaction with social life and family life was associated with being female and being a business student.

The findings from this study indicate that students who perform physical activity express higher levels of overall LS, which might be an interesting implication for further research to investigate whether LS lowers with age if physical activity increases. The optimum amount of physical engagement among students which positively affects LS is four to five hours a week. The results found here may provide foundations for further studies investigating how to improve LS among university students as well as serve as evidence for consideration among policy makers when drafting or debating legislation affecting university students.

Author Contributions: Conceptualization, T.S. and D.B.; methodology, T.S. and D.B.; software, D.B.; validation, D.B., D.P. and V.V.; formal analysis, D.B.; investigation, T.S.; resources, D.P.; data curation, V.V.; writing - original draft preparation, T.S. and V.V.; writing—review and editing, D.B. and D.P.; visualization, T.S. and V.V.; supervision, D.B.; project administration, D.P.; funding acquisition, D.B. All authors have read and agreed to the published version of the manuscript.

Funding: This research was funded by The Ministry of Education, Science and Technological Development of the Republic of Serbia: "Researching Contemporary Tendencies of Strategic Management Using Specialized Management Disciplines in Function of Competitiveness of Serbia Economy" and "Organizational and information support to the quality management system as a key factor in improving the competitiveness of domestic enterprises and ensuring their faster access to world and EU markets" grant number 179081 and 179001.

Institutional Review Board Statement: Ethical review and approval were waived for this study, due to all the surveys were conducted anonymously and only collected non-confidential data.

Informed Consent Statement: Informed consent was obtained from all subjects involved in the study.

Data Availability Statement: The data presented in this study are available on request from the corresponding author. 
Conflicts of Interest: The authors declare no conflict of interest. The funders had no role in the design of the study; in the collection, analyses, or interpretation of data; in the writing of the manuscript; or in the decision to publish the results.

\section{References}

1. Thapa, A.; Cohen, J.D.; Guffey, S.; Higgins-D'Alessandro, A. A Review of School Climate Research. Rev. Educ. Res. 2013, 83, 357-385. [CrossRef]

2. Kim, M.J.; Lee, H.; Kim, H.K.; Ahn, Y.-H.; Kim, E.; Yun, S.-N.; Lee, K.-J. Quality of Faculty, Students, Curriculum and Re-Sources for Nursing Doctoral Education in Korea: A Focus Group Study. Int. J. Nurs. Stud. 2010, 47, 295-306. [CrossRef] [PubMed]

3. Smith, S.Y.; Curbow, B.; Stillman, F.A. Harm Perception of Nicotine Products in College Freshmen. Nicotine Tob. Res. 2007, 9, 977-982. [CrossRef] [PubMed]

4. Von Ah, D.; Ebert, S.; Ngamvitroj, A.; Park, N.; Kang, D.-H. Predictors of Health Behaviours in College Students. J. Adv. Nurs. 2004, 48, 463-474. [CrossRef] [PubMed]

5. Diener, E.; Diener, M.L. Cross-Cultural Correlates of Life Satisfaction and Self-Esteem. In Culture and Well-Being: The Collected Works of Ed Diener, Social Indicators Research Series; Diener, E., Ed.; Springer Science and Business Media: New York, NY, USA, 2009; Volume 38, pp. 71-91.

6. Kim, E.S.; Kubzansky, L.D.; Smith, J. Life Satisfaction and Use of Preventive Health Care Services. Health Psychol. 2015, 34, 779-782. [CrossRef]

7. Park, C.L.; Armeli, S.; Tennen, H. The Daily Stress and Coping Process and Alcohol Use among College Students. J. Stud. Alcohol 2004, 65, 126-135. [CrossRef]

8. Fosnacht, K.; McCormick, A.C.; Lerma, R. First-Year Students' Time Use in College: A Latent Profile Analysis. Res. High. Educ. 2018, 59, 958-978. [CrossRef]

9. Hamaideh, S.H. Stressors and Reactions to Stressors Among University Students. Int. J. Soc. Psychiatry 2009, 57, 69-80. [CrossRef]

10. Hammoud, S.; Karam, R.; Mourad, R.; Saad, I.; Kurdi, M. Stress and Heart Rate Variability during University Final Examina-tion among Lebanese Students. Behav. Sci. 2018, 9, 3. [CrossRef] [PubMed]

11. Plant, E.A.; Ericsson, K.A.; Hill, L.; Asberg, K. Why Study Time Does Not Predict Grade Point Average across College Students: Implications of Deliberate Practice for Academic Performance. Contemp. Educ. Psychol. 2005, 30, 96-116. [CrossRef]

12. Garber, M.C.; Huston, S.A.; Breese, C.R. Sources of Stress in a Pharmacy Student Population. Curr. Pharm. Teach. Learn. 2019, 11, 329-337. [CrossRef] [PubMed]

13. Reysen, R.H.; Degges-White, S.; Reysen, M.B. Exploring the Interrelationships Among Academic Entitlement, Academic Performance and Satisfaction with Life in a College Student Sample. J. Coll. Stud. Retent. Res. Theory Pract. 2017, 22, 186-204. [CrossRef]

14. Parker, J.D.; Summerfeldt, L.J.; Hogan, M.J.; Majeski, S.A. Emotional Intelligence and Academic Success: Examining the Transition from High School to University. Pers. Individ. Differ. 2004, 36, 163-172. [CrossRef]

15. Toraman, Ç.; Özdemir, H.F.; Koşan, A.M.A.; Orakc1, Ş. Relationships between Cognitive Flexibility, Perceived Quality of Faculty Life, Learning Approaches, and Academic Achievement. Int. J. Instr. 2020, 13, 85-100. [CrossRef]

16. Tay, L.; Batz, C.; Parrigon, S.; Kuykendall, L. Debt and Subjective Well-being: The Other Side of the Income-Happiness Coin J. Happiness Stud. 2017, 18, 903-937. [CrossRef]

17. Kumar, M.K.; Priyadarshini, R.G. Important Factors of Self-Efficacy and Its Relationship with Life Satisfaction and Self-Esteemwith Reference to Gen Y and Gen Z Individuals. IOP Conf. Ser. Mater. Sci. Eng. 2018, 390, 012007. [CrossRef]

18. Andrews, B.; Wilding, J. The Relation of Depression and Anxiety to Life-Stress and Achievement in Students. Br. J. Psychol. 2004, 95, 509-521. [CrossRef]

19. Misra, R.; Castillo, L.G. Academic Stress Among College Students: Comparison of American and International Students. Int. J. Stress Manag. 2004, 11, 132-148. [CrossRef]

20. Jenkins-Guarnieri, M.A.; Vaughan, A.L.; Wright, S.L. Development of a Self-Determination Measure for College Students. Meas. Eval. Couns. Dev. 2015, 48, 266-284. [CrossRef]

21. West, C.P.; Shanafelt, T.D.; Kolars, J.C. Quality of Life, Burnout, Educational Debt, and Medical Knowledge Among Internal Medicine Residents. JAMA 2011, 306, 952-960. [CrossRef]

22. Van Der Horst, K.; Paw, M.J.C.A.; Twisk, J.W.R.; Mechelen, W.V. A Brief Review on Correlates of Physical Activity and Sedentariness in Youth. Med. Sci. Sports Exerc. 2007, 39, 1241-1250. [CrossRef] [PubMed]

23. Von Rosen, P.; Olofsson, O.; Väsbom, S.; Heijne, A. Correlates of Health in Adolescent Elite Athletes and Adolescents: A CrossSectional Study of 1016 Adolescents. Eur. J. Sport Sci. 2018, 19, 707-716. [CrossRef] [PubMed]

24. Faro, J.; Wright, J.A.; Hayman, L.L.; Hastie, M.; Gona, P.N.; Whiteley, J.A. Functional Resistance Training and Affective Re-sponse in Female College-Age Students. Med. Sci. Sports Exerc. 2019, 51, 1186-1194. [CrossRef] [PubMed]

25. Meng, H.; Huang, P.; Hou, N.; Fan, J. Social Self-Efficacy Predicts Chinese College Students' First-Year Transition: A Four-Wave Longitudinal Investigation. J. Career Assess. 2015, 23, 410-426. [CrossRef]

26. Diaz, R.; Miller, E.K.; Kraus, E.; Fredericson, M. Impact of Adaptive Sports Participation on Quality of Life. Sports Med. Arthrosc. Rev. 2019, 27, 73-82. [CrossRef] 
27. Van Dyck, D.; De Bourdeaudhuij, I.; Deliens, T.; Deforche, B. Can Changes in Psychosocial Factors and Residency Explain the Decrease in Physical Activity During the Transition from High School to College or University? Int. J. Behav. Med. 2015, 22, 178-186. [CrossRef]

28. Gómez-Pinilla, F.; Hillman, C. The Influence of Exercise on Cognitive Abilities. Compr. Physiol. 2013, 3, 403-428. [CrossRef]

29. Arslan, S.; Akkas, O.A. Quality of College Life (QCL) of Students in Turkey: Students' Life Satisfaction and Identification. Soc. Indic. Res. 2013, 115, 869-884. [CrossRef]

30. MacCann, C.; Roberts, R.D. Just as Smart but Not as Successful: Obese Students Obtain Lower School Grades but Equivalent Test Scores to Nonobese Students. Int. J. Obes. 2012, 37, 40-46. [CrossRef]

31. Blaine, B. Does Depression Cause Obesity? J. Health Psychol. 2008, 13, 1190-1197. [CrossRef]

32. Masuda, A.; Muto, T.; Tully, E.C.; Morgan, J.; Hill, M.L. Comparing Japanese College Students' and U.S. College Students' Disordered Eating, Distress, and Psychological Inflexibility. J. Cross-Cultural Psychol. 2014, 45, 1162-1174. [CrossRef]

33. Laredo-Aguilera, J.A.; Cobo-Cuenca, A.I.; Santacruz-Salas, E.; Martins, M.M.; Rodríguez-Borrego, M.A.; López-Soto, P.J.; Carmona-Torres, J.M. Levels of Physical Activity, Obesity and Related Factors in Young Adults Aged 18-30 during 2009-2017. Int. J. Environ. Res. Public Health 2019, 16, 4033. [CrossRef]

34. Crosnoe, R. Body Mass Index, Academic Achievement, and School Context: Examining the Educational Experiences of Adolescents at Risk of Obesity. J. Health Soc. Behav. 2017, 45, 393-407. [CrossRef] [PubMed]

35. Ter Bogt, T.F.M.; Van Dorsselaer, S.A.F.M.; Monshouwer, K.; Verdurmen, J.E.E.; Engels, R.C.M.E.; Vollebergh, W.A.M. Body Mass Index and Body Weight Perception as Risk Factors for Internalizing and Externalizing Problem Behavior Among Ado-lescents. J. Adolesc. Health 2006, 39, 27-34. [CrossRef] [PubMed]

36. Witherspoon, D.; Latta, L.; Wang, Y.; Black, M.M. Do Depression, Self-Esteem, Body-Esteem, and Eating Attitudes Vary by BMI Among African American Adolescents? J. Pediatr. Psychol. 2013, 38, 1112-1120. [CrossRef] [PubMed]

37. Lee, K.J.; Lee, S.M. The Role of Self-Compassion in the Academic Stress Model. Curr. Psychol. 2020, 1-10. [CrossRef]

38. Lilleholt, L.; Aaby, A.; Makransky, G. Students Admitted to University Based on a Cognitive Test and MMI Are Less Stressed Than Students Admitted Based On GPA. Stud. Educ. Eval. 2019, 61, 170-175. [CrossRef]

39. Antaramian, S.; Lee, J. The Importance of Very High Life Satisfaction for Students' Academic Success. Cogent Educ. 2017, 4, 4. [CrossRef]

40. Reisbig, A.M.; Danielson, J.A.; Wu, T.-F.; Hafen, M.; Krienert, A.; Girard, D.; Garlock, J. A Study of Depression and Anxiety, General Health, and Academic Performance in Three Cohorts of Veterinary Medical Students across the First Three Semesters of Veterinary School. J. Veter.-Med. Educ. 2012, 39, 341-358. [CrossRef]

41. Abell, S.K. University Science Teachers as Researchers: Blurring the Scholarship Boundaries. Res. Sci. Educ. 2005, 35, 281-298. [CrossRef]

42. Stanojević, D.; Tomanović, S.; Ljubičić, M. Elements of Life Satisfaction among Young Adults in Serbia. J. Youth Stud. 2016, 19, 1-17. [CrossRef]

43. Strenze, T. Intelligence and Socioeconomic Success: A Meta-Analytic Review of Longitudinal Research. Intelligence 2007, 35, 401-426. [CrossRef]

44. Cabras, C.; Mondo, M. Future Orientation as a Mediator Between Career Adaptability and Life Satisfaction in University Students. J. Career Dev. 2018, 45, 597-609. [CrossRef]

45. Richardson, M.; Abraham, C.; Bond, R. Psychological Correlates of University Students' Academic Performance: A Systematic Review and Meta-Analysis. Psychol. Bull. 2012, 138, 353-387. [CrossRef] [PubMed]

46. Anđić, T. Futurelessness, Migration, or a Lucky Break: Narrative Tropes of the 'Blocked Future' among Serbian High School Students. J. Youth Stud. 2020, 23, 430-446. [CrossRef]

47. Hazar, K.; Şenbakar, K. The Relationship between Exercise Addiction and Satisfaction with Life in Physical Education and Sport Department Students. Asian J. Educ. Train. 2020, 6, 12-17. [CrossRef]

48. Bjelica, D.L.; Jovanović, U.D. It's Up to You: The Influence of Sports Participation, Academic Performances and Demo-Behavioral Characteristics on University students' Life Satisfaction. Appl. Res. Qual. Life 2014, 11, 163-179. [CrossRef]

49. WHO Body Mass Index-BMI. Available online: https://www.euro.who.int/en/health-topics/disease-prevention/nutrition/ahealthy-lifestyle/body-mass-index-bmi (accessed on 27 October 2020).

50. Valois, R.F.; Zullig, K.J.; Huebner, E.S.; Drane, J.W. Physical Activity Behaviors and Perceived Life Satisfaction Among Public High School Adolescents. J. Sch. Health 2004, 74, 59-65. [CrossRef]

51. Zullig, K.J.; Huebner, E.S.; Gilman, R.; Patton, J.M.; Murray, K.A. Validation of the Brief Multidimensional Students' Life Satis-Faction Scale among College Students. Am. J. Health Behav. 2005, 29, 206-214. [CrossRef]

52. Huebner, E.S.; Seligson, J.L.; Valois, R.F.; Suldo, S.M. A Review of the Brief Multidimensional Students' Life Satisfaction Scale. Soc. Indic. Res. 2006, 79, 477-484. [CrossRef]

53. Rode, J.C.; Arthaud-Day, M.L.; Mooney, C.H.; Near, J.P.; Baldwin, T.T.; Bommer, W.H.; Rubin, R.S. Life Satisfaction and Student Performance. Acad. Manag. Learn. Educ. 2005, 4, 421-433. [CrossRef]

54. Heffner, A.L.; Antaramian, S.P. The Role of Life Satisfaction in Predicting Student Engagement and Achievement. J. Happiness Stud. 2016, 17, 1681-1701. [CrossRef] 
55. Grass, J.; Strobel, A.; Strobel, A. Cognitive Investments in Academic Success: The Role of Need for Cognition at University. Front. Psychol. 2017, 8, 790. [CrossRef] [PubMed]

56. Steinmayr, R.; Heyder, A.; Naumburg, C.; Michels, J.; Wirthwein, L. School-Related and Individual Predictors of Subjective Well-Being and Academic Achievement. Front. Psychol. 2018, 9, 9. [CrossRef] [PubMed]

57. Curran, M.; Parrott, E.; Ahn, S.Y.; Serido, J.; Shim, S. Young Adults' Life Outcomes and Well-Being: Perceived Financial Socialization from Parents, the Romantic Partner, and Young Adults' Own Financial Behaviors. J. Fam. Econ. Issues 2018, 39, 445-456. [CrossRef]

58. Harrison, N.; Davies, S.; Harris, R.; Waller, R. Access, Participation and Capabilities: Theorising the Contribution of University Bursaries to Students' Well-Being, Flourishing and Success. Camb. J. Educ. 2018, 48, 1-19. [CrossRef]

59. Cloutier, J.; Roy, A. Consumer Credit Use of Undergraduate, Graduate and Postgraduate Students: An Application of the Theory of Planned Behaviour. J. Consum. Policy 2020, 43, 565-592. [CrossRef]

60. Murphy, J.G.; McDevitt-Murphy, M.E.; Barnett, N.P. Drink and Be Merry? Gender, Life Satisfaction, and Alcohol Consumption Among College Students. Psychol. Addict. Behav. 2005, 19, 184-191. [CrossRef]

61. Ismael Alorani, O.; Fuad Alradaydeh, T. Spiritual Well-Being, Perceived Social Support, and Life Satisfaction among University Students. Int. J. Adolesc. Youth 2018, 23, 291-298. [CrossRef]

62. Pesic, J. Persistence of Traditionalist Value Orientations in Serbia. Sociology 2006, 48, 289-307. [CrossRef]

63. Moo-Estrella, J.; Pérez-Benítez, H.; Solís-Rodríguez, F.; Arankowsky-Sandoval, G. Evaluation of Depressive Symptoms and Sleep Alterations in College Students. Arch. Med Res. 2005, 36, 393-398. [CrossRef] [PubMed]

64. Allam, Z.; Azam, M. Exploring the Predictors of Student Satisfaction: A Case of Undergraduate Business School in King-dom of Saudi Arabia. Univers. J. Educ. Res. 2020, 8, 5760-5767. [CrossRef]

65. Jetzke, M.; Mutz, M. Sport for Pleasure, Fitness, Medals or Slenderness? Differential Effects of Sports Activities on Well-Being. Appl. Res. Qual. Life 2019, 15, 1-16. [CrossRef]

66. Romaguera, D.; Tauler, P.; Bennasar, M.; Pericas, J.; Moreno, C.; Martinez, S.; Aguilo, A. Determinants and Patterns of Phys-Ical Activity Practice among Spanish University Students. J. Sports Sci. 2011, 29, 989-997. [CrossRef]

67. Northern, J.J.; O'Brien, W.H.; Goetz, P.W. The Development, Evaluation, and Validation of a Financial Stress Scale for Undergraduate Students. J. Coll. Stud. Dev. 2010, 51, 79-92. [CrossRef]

68. Eime, R.; Payne, W.; Harvey, J. Trends in Organised Sport Membership: Impact on Sustainability. J. Sci. Med. Sport 2009, 12, 123-129. [CrossRef]

69. Flosdorf, M.L.; Carr, B.H.; Carr, J.W.; Pate, J.R. An Exploration of the Sport Club President's Experience. Recreat. Sports J. 2016, 40, 106-119. [CrossRef]

70. Schnettler, B.; Miranda-Zapata, E.; Grunert, K.G.; Lobos, G.A.; Denegri, M.; Hueche, C.; Poblete, H. University Student Profiles According to Satisfaction with Life, Food and Family. Rev. Chil. Nutr. 2018, 45, 263-270. [CrossRef]

71. De Wit, L.; Van Straten, A.; Van Herten, M.; Penninx, B.; Cuijpers, P. Depression and Body Mass Index, a U-Shaped Association. BMC Public Health 2009, 9, 14. [CrossRef]

72. Wiklund, E.; Jonsson, E.; Coe, A.-B.; Wiklund, M. 'Strong Is the New Skinny': Navigating Fitness Hype among Teenagers in Northern Sweden. Sport Educ. Soc. 2019, 24, 441-454. [CrossRef]

73. Djokic, I.; Grubor, A.; Milicevic, N.; Djokic, N. Increasing Students' Physical Activity in Function of Social Sustainability: Rec-ommendations from a Social Marketing Perspective. Sustainability 2020, 12, 3303. [CrossRef]

74. Wilson, G.; Gillies, R.J. Stress Associated With the Transition From High School to University: The Effect of Social Support and Self-Efficacy. Aust. J. Guid. Couns. 2005, 15, 77-92. [CrossRef]

75. Miller, K.E.; Hoffman, J.H. Mental Well-Being and Sport-Related Identities in College Students. Sociol. Sport J. 2009, 26, 335-356. [CrossRef]

76. Castro-Sánchez, M.; Zurita-Ortega, F.; Chacón-Cuberos, R. Motivation Towards Sport Based on Sociodemographic Variables in University Students from Granada. J. Sport Health Res. 2019, 11, 55-68.

77. DeWitt, D.; Canny, B.J.; Nitzberg, M.; Choudri, J.; Porter, S. Medical Student Satisfaction, Coping and Burnout in Direct-Entry versus Graduate-Entry Programmes. Med. Educ. 2016, 50, 637-645. [CrossRef] [PubMed]

78. Rettig, J.; Hu, S. College Sport Participation and Student Educational Experiences and Selected College Outcomes. J. Coll. Stud. Dev. 2016, 57, 428-446. [CrossRef]

79. Arzu, D.; Tuzun, E.H.; Eker, L. Perceived Barriers to Physical Activity in University Students. J. Sports Sci. Med. 2006, 5, 615-620.

80. Deliens, T.; Deforche, B.; De Bourdeaudhuij, I.; Clarys, P. Determinants of Physical Activity and Sedentary Behaviour in Uni-Versity Students: A Qualitative Study Using Focus Group Discussions. BMC Public Health 2015, 15, 201. [CrossRef]

81. Viñas Poch, F.; Villar, E.; Caparros, B.; Juan, J.; Cornella, M.; Perez, I. Feelings of Hopelessness in a Spanish University PopulaTion-Descriptive Analysis and Its Relationship to Adapting to Universi-Ty, Depressive Symptomatology and Suicidal Ideation. Soc. Psychiatry Psychiatr. Epidemiol. 2004, 39, 326-334. [CrossRef] [PubMed]

82. Finch, D.J.; Hamilton, L.K.; Baldwin, R.; Zehner, M. An Exploratory Study of Factors Affecting Undergraduate Employability. Educ. + Train. 2013, 55, 681-704. [CrossRef]

83. Feldman, A.; Divoll, K.A.; Rogan-Klyve, A. Becoming Researchers: The Participation of Undergraduate and Graduate Stu-dents in Scientific Research Groups. Sci. Educ. 2013, 97, 218-243. [CrossRef] 
84. Jordan, K.A.; Gagnon, R.J.; Anderson, D.M.; Pilcher, J.J. Enhancing the College Student Experience: Outcomes of a Leisure Education Program. J. Exp. Educ. 2018, 41, 90-106. [CrossRef]

85. Baloran, E.T. Knowledge, Attitudes, Anxiety, and Coping Strategies of Students during COVID-19 Pandemic. J. Loss Trauma 2020, 25, 1-8. [CrossRef] 